Отримано: 19 серпня 2021 року

Прорецензовано: 6 вересня 2021 року

Прийнято до друку: 20 вересня 2021 року

e-mail: olga.kachmar@uzhnu.edu

DOI: $10.25264 / 2519-2558-2021-11(79)-80-84$
Kachmar O. Yu. Economic discourse as a type of institutional discourse. Наукові записки Наиіонального університету «Острозька академія»: серія «Філологія». Острог : Видво НаУОА, 2021. Вип. 11(79). С. 80-84.

Olga Kachmar,

PhD in Philology, Associate Professor,

SU "Uzhhorod National University"

\title{
ECONOMIC DISCOURSE AS A TYPE OF INSTITUTIONAL DISCOURSE
}

The research deals with the study of the English language economic discourse and its basic characteristics.

The object of the article is discourse in general and the main approaches to its interpretation. The subject of the investigation is the English economic discourse as one of its institutional types. The aim of the research is to highlight the main linguistic characteristics of the English economic discourse.

Economic discourse is defined as a type of discourse, in which the process of speech production based on certain economic ideas. Each of the texts of discourse creates a special field of discussion in relation to economy, and the texts within this discourse are aimed at the communication between the experts in the field which determines the institutionality of the communication. Thus, economic discourse is a complex communicative phenomenon implemented in the speech practice of subjects of economic activity.

The characteristic features of the economic discourse are strict visual design, minimum usage of tropes and figures of speech, the use of persuasive devices, neologisms, idioms and numerous abbreviations used with the aim of compressing the transmitted knowledge.

Neologisms, idioms and abbreviations that function in English economic discourse present special difficulties for translators. Therefore the perspective of the further research is seen in the study of translation techniques in reproducing various lexical, grammatical and syntactical features of the English economic discourse into the Ukrainian language.

Key words: discourse, text, communication, idiom, abbreviation, institutionality

\section{Качмар Ольга Юріївна,}

Кандидат філологічних наук, доиент,

ДВНЗ «Уэсгородський начіональний університет»

\section{ЕКОНОМІЧНИЙ ДИСКУРС ЯК РІЗНОВИД ІНСТИТУЦІйНОГО ДИСКУРСУ}

Дослідження присвячене висвітленню загальних характеристик дискурсу, а також виявленню мовних особливостей економічного дискурсу.

Економічний дискурс визначено як вид дискурсу, в якому проиес мовленнєвого продукування базується на певних економічних ідеях. Кожен з текстів иього дискурсу створює особливе поле для дискусії у сфері економіки, а тексти в межах иього дискурсу спрямовані на комунікацію між експертами в иій галузі, що визначає інституційність комунікації. Таким чином, економічний дискурс - ие складне комунікативне явище, реалізоване у мовній практиці суб'єктів економічної діяльності.

Характерними особливостями економічного дискурсу є строгий візуальний дизайн, мінімальне використання тропів і фігур мови, використання персуазивних прийомів, неологізмів, ідіом та численних абревіатур, що використовуються з метою компресії переданого знання.

Ключові слова: дискурс, текст, комунікація, ідіома, абревіатура, інституиійність.

The term «discourse» has been employed in many ways for infinite purposes. Historically, the term «discourse» has been applied to more rehearsed forms of spoken language (i.e. speeches) than to spontaneous speech. It has also been used to make reference to the topics and types of language used in particular contexts (i.e. the legal discourse, the medical discourse, the religious discourse) [22, p. 666].

There is no single common definition of this concept or an integrated approach to this phenomenon since different scholars offer their interpretation of the concept «discourse». The term «discourse analysis» was introduced for the first time by the American linguist Zellig Harris. The scholar used this term as a tool of coherent speech analysis using a distributive method. Later, this term began to be associated with the «German term «Textlinguistik» and also with the term «linguistica del texto» by E. Koseriu [5], that is, the terms «text» and «discourse» were identified. The delineation of these terms begins with the end of the 70's - early 80 's of the twentieth century $[8$, p. 670].

In linguistics, the term pointed such types of utterances in the contexts of linguistic analytics, which showed a specific piece of speech through describing the relationship between utterance and the addressee, clarifying structure between aspects expressed here-and-now (speech) and being expressed (impersonal, relatively independent plot or story), and speaker and recipient, which «appropriates» the speaker's opinion [6, p. 196-197].

Sara Mills notes that the term «discourse» has much more interpretations than all other terms of literary criticism and the theory of culture [19, p. 1]. In French linguistics, the term «discourse» possesses the meaning of «speech, text». Emile Benveniste was one of the first scholars to clarify this notion, namely, to define discourse as a speech belonging to a speaker. T. van Dijk, a wellknown linguist [14, p. 48], notes that the term «discourse» can be used in the following meanings: discourse in the broad sense can be written, oral, and also have a verbal and nonverbal component; discourse in a narrow sense is determined by the researcher as a written or verbal product of communicative action; discourse as a particular conversation is always associated with specific conditions and context; discourse as a type of conversation is associated with the types of verbal production, and not with concrete communicative actions; discourse as a genre, namely, scientific discourse, political discourse, and so on; discourse as a generalized idea of a particular historical period, culture, community. 
According to Oxford Dictionary, discourse is written or spoken communication or debate [15]. According to other definitions, a discourse is a set of meanings through which a group of people communicate about a particular topic. Discourse can be defined in a narrow or a broad sense and a narrow definition of discourse might refer only to spoken or written language. However, discourse analysis more often draws on a broader definition to include the shared ways in which people make sense of things within a given culture or context, including both language and language-based practices (i.e. the ways in which things are accomplished) [16]. Discourse is defined in this research as «a continuous stretch of language containing more than one sentence: conversations, narratives, arguments, speeches. Discourse analysis is the social and linguistic description of norms governing such productions, and may include (in critical linguistics) focuses upon the social and political determinants of the form discourse takes; for instance, the hidden presuppositions that the persons addressed are of a certain class, race, or gender» [18, p. 1].

Thus, discourse incorporates all of its possible modes, i.e. spoken or written forms as well as the monologue or the dialogue. The first pair is distinguished under the category of the medium; the second pair, on the other side, represents the result of the nature of the participation during a concrete communicative event and may be brought together under the heading of various aspects of modality. All of these four forms have their typical features; nevertheless, it sometimes happens that features that are usually associated with informal dialogic speech are part of a written text, or, on the contrary, when some formal features usually ascribed to writing are used in a public speech [13, p. 69].

David Crystal remarks that «any piece of discourse contains a large number of features which are difficult to relate to specific variables to in the original extra-linguistic context even though they may be felt to have some kind of stylistic value» [13, p. 63]. The analysis, thus, should be performed very carefully in order to catch all contextual features as much as it is possible.

The scholars Gillian Brown and George Yule describe discourse as «a dynamic process in which language was used as an instrument of communication in a context by a speaker/writer to express meaning and achieve intentions» [11, p. 26]. Similar definition of discourse is offered by Guy Cook who describes discourse as «the language in use, for communication» [12, p. 6]. He adds that discourse should be coherent and he explains that language that is used to teach language or literacy is not a discourse [12, p. 6]. In his scientific work «Discourse» published in 1990, the linguist states that novels, as well as short conversations might be equally reasonably called discourses. The author also emphasizes that «discourse is text and context together, interacting in a way which is perceived as meaningful and unified by the participants (who are both part of the context and observers of it)» [12, p. 2].

In Henry Widdowson's point of view, the term «discourse» refers «both to what a text producer meant by a text and what a text means to the receiver». As it follows from this perspective, it is possible that the receiver infers a different discourse from the text than a text producer has intended. H. Widdowson states that «people produce texts to get a message across, to express ideas and beliefs, to explain something to get other people to do certain things or to think in a certain way» [24, p. 6].

In our interpretation discourse is defined as a coherent text in combination with extra-linguistic-pragmatic, socio-cultural, psychological and other factors; as a text taken in the conceptual aspect; as a purposeful social action that characterizes the interaction of people and the mechanism of their consciousness. In this sense, the discourse is presented not as a static object of the existential space of the linguistic community, but rather as a model of dynamic communication [4, p. 70]. A characteristic feature of discourse research is the two-way orientation of the vector of scientific analysis in the «discourse-personality» correlation, when a language personality is defined through a discourse, and vice versa - discourse is studied in its action, in functioning through a language personality.

Summing up, it can be argued that, despite a large number of definitions of the concept «discourse», it remains blurred and ambiguous. Proceeding from this, we can attribute this concept to linguistic universals, because every day its interpretation extends.

F. Batsevych classifies discourse as a communicative phenomenon for such communicative features: the manifestations of communication in society (communicative discourse, linguistic, verbal, nonverbal, contemporary discursive practices, discourse of silence); communication within individual channels (visual, auditory, tactile); a manifestation of the rules of communication, ways of presenting and translating the pragmatic purpose of the speakers (etiquette, swindling, didactic). Systematizing various typological researches, F. Batsevych distinguishes discourse from identification with the subject of research of various sciences; perceiving as an expression of cultural communication; ethno-cultural peculiarities of communication; cultural and historical peculiarities of communication; social, age and sexual characteristics communication participants; types and forms of speech, the principles of giving the message, his rhetoric; the characteristics of the broadcast of an individual and groups of people [1, p. 153-154].

One of the most trusted ones is the typology of discourse offered by G. Pocheptsov, whose classification is based on various types of semiotic characters (literary, folklore, mythological, ritual, theatrical, informal (obscurant), false, cursory, etiquette discourses, etc.). The researcher also highlights newspaper, theater, television and radio discourses, film discourse, discourse in the field of public relations (PR), advertising, political, religious (fideistic) discourses [7, p. 75-90].

Of particular interest are some of the provisions of the Ukrainian linguists I. Shevchenko and O. Morozova [9, p. 233-236.] who proposed the following criteria for the distinction between the types and subtypes of discourse:

1) in the form: oral and written;

2) according to the type of speech: monologue or dialogue;

3) according to the specific direction: institutional and personal;

4) under various guidelines and communicative principles: an argumentative, conflict and harmonious discourse;

5) according to the socially situational parameter: political, administrative, legal, military, religious, medical, business, advertising, pedagogical, sports, scientific, electronic (Internet discourse), media discourse (mass media), etc.

6) according to various characteristics of the sender and the addressee: socially-demographic criterion (childhood, teen discourse and discourse of the elderly, female and male discourse, discourse of the inhabitants of the city and the village); social-professional criterion: discourse of sailors, builders, miners, economists; socio-economic political criterion (discourse of the Communists, Democrats);

7) according to the functional and informative components: informative communication (emotional, appraisal, policy discourse) and factual;

8) according to the criterion of formality and content in functionality aspect in accordance with genres and speech registers: artistic, journalistic, scientific, official and informal [9, p. 233-236]. 
It should be noted that typologically different discourses correlate with each other, determine each other and have common features in their structure. The selection of one or another principle of the classification of discourse depends on its relevance for the modern linguistic paradigm and the direction of research. The basis for distinguishing the appropriate types of discourse can be formal, functional, meaningful criteria. The emergence of new types and subtypes of discourse leads to updating the classification.

According to its specific direction, discourse is classified into personal and institutional one. Institutional discourse is a form of «social practice», a kind of communication. Here communicants realize their roles in a limited set of features, and, of course, act as members of certain status groups [3, p. 54].

In short, institutional discourse can be described as talk which sets up positions for people to talk from and restricts some speakers' access to certain kinds of discursive actions. For instance, in media settings, the role of a TV or radio news interviewer typically (although not exclusively) involves doing the questions, while the role of interviewee involves doing the answers; in the context of a family meal-time, research has shown that children typically are the ones who are asked to tell the story of their day, while it is mostly mothers who elicit the stories and fathers who are the primary recipients, and evaluators, of the events being recounted [21, p. 4].

Since the early 1980s, the discussion of various controversial issues in the economics discourse community has led to increasing debate among concerned economists about the ways that they communicate with each other, as well as with non-economists. This debate has been vigorous, and has also influenced the direction and nature of the research into economics discourse by applied linguists [23, p. 16].

Economic discourse is professional discourse. From the sociolinguistic point of view, professional discourse represents the institutional communication of people who have received special training to perform a certain work activity. The sociolinguistic description of discourse consists in describing its institutional, profile and subject characteristics.

Economic discourse is interwoven in interpersonal communication. In this interpretation, it appears as an extended understanding of the text, as the text immersed in a professional communicative situation with knowledge of the participants in the communication and the conditions of the situation. Consequently, it follows from this definition that the main characteristics of professional discourse are the coherence of the text, the eventual aspect, the conditionality of extra-linguistic factors and the purposefulness of social action.

Economic discourse can be characterized as a synthesis of professional identities that are realized in the communicative activities of the modern specialist. The approach to the structure of this discourse as its architectonics, i.e. the basic principle of construction, connections and interdependence of the elements of the whole allows to analyze different levels of real professional communication, because in each of its zones there is the interpretation of information implemented in determining its depth, level of language signs, the amount of knowledge presented in the definition, etc.

The addresser-addressee approach allows to distinguish the qualification features of the professional discourse (professional orientation; anthropocentrism; creativity multidisciplinarity; disproportionate development of separate parts of the discourse, connected with asynchronous development of separate branches of knowledge and spheres of professional activity; dialogue; selectivity in the choice of a specific addressee; non-cyclicality; closeness; didacticism; language normality, etc.).

In our research we focus on economic professional discourse as a set of speech acts in the sphere of economics, as well as oral and written texts created by professionals, non-professionals and journalists or their fragments that reflect the realities of the economic world. The purpose of economic discourse is 1 ) to cover events in the economic life of society; 2) to inform about the state of the economy; 3) to form a certain attitude towards various changes and encourage certain actions; 4) to create economic theories; 5) to study the directions of economic development, as well as the living standards of the population.

The language of economic discourse is characterized by the diversity in the selection of language means and grammatical forms, the use of economic vocabulary, terms, abbreviations, economic neologisms and idioms, combinations of vocabulary of different genres, the lack of a single text construction. It is conditioned by the need to influence the addressee, to convey information and to induce appropriate actions $[10$, p. 45$]$.

Taking into account the above-mentioned characteristics of discourse, in order to define the essence of the concept of «economic discourse» we consider economic discourse to be a set of speech acts, which are used in defining and characterizing economic processes. In addition, there are oral and written whole texts or fragments thereof reflecting the realities of the economic world.

In order to analyze the interrelationship of economic discourse and abbreviations, neologisms, and idioms, we should address the notion of language for special purposes. The term language for special purposes (LSP) emerged in the early 1970s and was used to define the types of national languages that serve special spheres of social life.

The study of special variants of the language is an important direction of modern linguistics, the focus of which remains not only on the terminology systems, but also on the ways of organizing language means to solve communicative problems of the sphere of communication that is served by a particular special variant of the language. In today's conditions, personal knowledge and professional skills are not sufficient for successful professional performance. Professional communication acquires great importance - the ability to communicate in the appropriate language environment, i.e. to possess the conceptual apparatus, norms and rules of speech activity related to a particular professional sphere.

In the general professional activity of specialists, there is a communication caused by a range of interests, for which there is a limited exchange of information about joint work or study. Such cooperation uses professional notions, scientific and technical terminology, determines the degree of mutual understanding during the performance of joint work. The language of the profession is the main functional component of the professional communication, and its mastery is the primary task of any specialist. At the present stage, scientists pay special attention to studying the professional language, which serves the professional sphere of communication. The language of professional communication is a linguistically organized system of communication, used by representatives of a particular field to communicate in situations that are directly related to professional qualities (educational, production, scientific) of working life. Factors that determine the content of professionally oriented foreign language teaching of professional communication include the sphere of professionally oriented communication (industrial, industrial-commercial, scientific-production, scientific as well as professionally determined: social-political, socio-cultural and household spheres of professional communication), situations and topics of professionally oriented communication [2, p. 45-46]. 
Economic discourse is a type of discourse, in which the process of speech production is based on certain economic ideas (e.g., bankruptcy, fraud, taxes). It should be noted that there is an opinion that the economic discourse exists, especially in the economic texts, articles, and Internet publications. This set of articles allows talking about the formation of the economic discourse [17].

We distinguish two approaches to the definition of economic discourse. According to the first direction, economical discourse is a system of texts that arise under the influence of various factors (extra-linguistic, pragmatic, sociocultural, etc.) and united by one theme. In the light of the second approach, the economical discourse appears as a communicative event, as an integrative set of individual communicative acts in the sphere of economy. The verbal result of this discursive activity is economical texts.

The purposes of economic discourse are: 1) covering the events in the economic life of society; 2) informing about the state of the economy; 3 ) forming specific relationships of various changes and impulses to certain actions; 4) creating economic theories; 5) studying the areas of economic development, as well as the standard of living of the population.

Economists' assessments of their own discourse has contributed to a growing awareness by many that the ways they communicate their ideas in economics do not accurately correspond to the ways they actually «do» economics. The major figure amongst those economists who advocate that fellow economists should examine the ways they use their own discourse is D. McCloskey, an economic historian and economist, whose range of publications dealing with the «rhetoric of economics», has attracted academic interest from not only his economics colleagues, but also from applied linguists [23].

E. Pethő emphasized first that the same real economy is described by different groups of people differently, with different vocabulary. The highest level of economic discourse is a discourse among economists which is the scientific language. Good economics is expressed in a natural language, so it can be labeled as literary economics. The middle level is the academic discourse among businessmen. This language is professional, but scientifically not precise. Finally, the lowest level is the lay language in the discourse among common people [20, p.109-110].

Economic discourse has developed within the various economic schools of thought and even paradigms, in addition to existing and developing political and common economic discourses with the options in the direction of news journalism and mass journalism. Each of these types of discourse creates a special «field of discussion» in relation to market economy. The public distribution of the benefits of macroeconomic issues other aspects of economic realities. Thus, the economic discourses are divided based on the deepening of understanding and organization of economic reality.

Genre varieties of economic discourse can include Internet articles, news reports, interviews, commentaries, reviews, television and radio broadcasts, novels, newspaper satires, essays. Functional classification of economic discourse texts is based on the fact that the main differential features in the allocation of a certain class of texts are their primary function, i.e. the communicative purpose of communicating between addresser and addressee: 1) scientific economic texts; 2) the texts of the professional economic activity; 3) educational economical texts; 4) texts of non-professional economic activity.

The present research suggests the fragment for the stylistic and discourse analysis as an example of the text belonging to economic discourse by Sarwat Jahan and Ahmed Saber Mahmud "What Is Capitalism?" [21]. The discourse parameters of the given text determine it as one belonging to economic discourse. The text under consideration is educational text belonging to the economic discourse. It is worth mentioning that the basic distinctive features of educational texts are dialogic nature, axiological features (permanent relationship of evaluation by teacher and one who is taught), reversibility (permanent and diverse variation of form and content of what is said), interactivity, synchronous group involvement of participants in the discourse in the process of verbal interaction, interdiscursivity, intertextuality. The significant factors in the formation of educational texts are scientific nature, accuracy, coherence, consistency, completeness, availability of information, richness, diversity, clarity of speech, expressiveness.

First, the style of narration creates the impression of institutionality as the participants of the communication have certain status roles - the narrator as the expert in the sphere and the reader as one who aims to better understand the specifics of the issue (one who studies economics). The thematic nature of the analyzed text fragment is such economic issue as capitalism, an economic system based on the private ownership of the means of production and their operation for profit, and the characteristic features of this economic system. The accuracy of the material presentation also implies that this text is an educational text in the sphere of economics.

Among the tropes and figures of speech used in the text, only metaphor is distinguished: father of modern economics (Adam Smith); Capitalism is founded on the following pillars. However, there are numerous other techniques characteristic for educational texts in the sphere of economics, in particular:

1) citation: As Adam Smith, the 18th century philosopher and father of modern economics, said: "It is not from the benevolence of the butcher, the brewer, or the baker that we expect our dinner, but from their regard to their own interest»;

2) evaluative vocabulary: Free markets may not be perfect but they are probably the best way to organize an economy;

3) lexical means of persuasiveness: Free markets may not be perfect but they are probably the best way to organize an economy;

4) passive constructions: Capitalism is often thought of as an economic system in which private actors own and control property in accord with their interests, and demand and supply freely set prices in markets in a way that can serve the best interests of society [21].

Two specific levels of vocabulary are observed in the analyzed text:

1) proper names: names of economists such as Adam Smith, Sarwat Jahan, Ahmed Saber Mahmud, and names of the books like Wealth of Nations;

2) terminology: free markets; economy; capitalism; economic system; property; demand; supply; prices; markets; economic prosperity; capitalist economy; labor; money wages; socialism; means of production; social good; profits; private property; tangible assets; intangible assets; stocks; bonds; self-interest; competition; producers; consumers; market mechanism; consumption; production; investment; investors; customers;

3) economic idioms: capital gains; laissez-faire economies; mixed economies;

4) economic abbreviations: $C A-$ capital assets;

5) economic neologisms: voluntary exchange transaction [21]. 
Thus, economic discourse is defined as a type of discourse, in which the process of speech production is based on certain economic ideas. Each of the texts of discourse creates a special «field of discussion» in relation to economy, and texts within this discourse are aimed at the communication between the experts in the field and those who study it which determines the institutionality of the communication. The characteristic features of such texts are strict visual design, lack of tropes and figures of speech, the use of persuasive devices and numerous terminological units compressing the knowledge transmitted.

In general, the English-language economic discourse is a complex communicative phenomenon with the above linguistic and socio-cultural peculiarities and is implemented in the speech practice of subjects of economic activity. The extra-linguistic plane of the discourse is formed by the context in the broad sense, various cognitive aspects, and consciousness of communicators. The extralinguistic factors of oral discourse include the peculiarities of the speaker's communicative behavior: culture of speech, speech etiquette of business communication, expressiveness, optimal tempo of speech adopted for the listeners, voice control, orderliness and sequence of thought presentation, appropriate intonation, gesticulation, facial expressions, logical and psychological pauses, correct logical accents. All these extra-linguistic factors are actively involved in the processes of generating and perceiving economic discourse.

\section{Література:}

1. Бацевич Ф. С. Основи комунікативної лінгвістики : підручник. Київ : Видавничий центр «Академія», 2004. 344 с.

2. Гапон Ю. А. Специфіка дисципліни і фактори, що визначають зміст навчання іноземної мови професійної спрямованості. Лінгвометодичні концепчії викладання іноземних мов у немовних вищих навчальних закладах України : зб. ст. Київ, 2003. С. 40-49.

3. Касумова М. Ю. Компьютерный дискурс как полиаспектаная разновидность речи. Вісник Дніпропетровського університету. 2009. № 15 (2). C. 52-59. URL: http://archive.nbuv.gov.ua/portal/natural/vdpu/Movozn/2009_15 2/article/9.pdf.

4. Качмар О. Ю. Дискурс як простір реалізації ментальних структур. Вісник Київського національного лінгвістичного університету. Сер. : Філологія. 2014. Т. 17, № 2. С. 70-76.

5. Косериу Е. Современное положение в лингвистике. Известия АН СССР. Серия литературы и языка. 1977. № 6. С. 45-47.

6. Літературознавчий словник-довідник / за ред. Р. Т. Гром’яка, Ю. І. Коваліва, В. І. Теремка. Київ : ВЦ «Академія», 2007. 752 с.

7. Почепцов Г. Г. Теорія комунікації. Київ : Спілка рекламістів України, Українська асоціація паблік рілейшнз, 1996.175 с.

8. Степанов Ю. С. Между системой и текстом - дискурс. Язык и метод. К современной философии языка. Москва : Языки русской культуры, 1998. С. 655-688.

9. Шевченко І. С., Морозова О. І. Проблеми типології дискурсу. Дискурс як когнітивно-комунікативний феномен : монографія / за загальн. ред. І. С. Шевченко. Харків : Константа, 2005. С. 233-236.

10. Шереметьева А. А. Основные характеристики экономического дискурса (на материале немецкого языка). Вестн. гос. пед. акад. 2011. № 7 (13). URL: http://vestnik.kuzspa.ru/articles/61

11. Brown G., Yule G. Discourse Analysis. Cambridge : Cambridge Univ. Press, 1983. 288 p.

12. Cook G. Discourse. Oxford : OUP, 1989. 342 p.

13. Crystal D. An Encyclopaedic Dictionary of Language and Languages. New Jersey : Blackwell Pub, 2004. 250 p.

14. Dijk T. A. van. Discourse Studies: A Multidisciplinary Introduction. Sage Publications Ltd., 2011. 432 p

15. Discourse. Oxford Online Dictionary. URL: http://oxforddictionaries. com/definition/english/discourse?q=discourse.

16. Discourse Analysis. URL: http://www.cprjournal.com/documents/discourseAnalysis.pdf.

17. Discourse markers. URL: http://grammar.about.com./od/dg/discourse marker.html.

18. Haase F.-A. The history of discourse as literary history. A parte rei. 2010. Vol. 20. P. 1-15.

19. Mills S. Discourse. Psychology Press, 2004. 168 p.

20. Pethő E. Introduction to rhetorical economics. European Integration Studies. 2005. Vol. 4. No. 1. P. 109-114.

21. Power, talk and institutional discourse: some key concepts. URL: ftp://ftp.awl.co.uk/Longacre/SampleChaps/longman/0582368790. pdf. Sarwat Jahan and Ahmed Saber Mahmud. What Is Capitalism? https://www.imf.org/external/pubs/ft/fandd/2015/06/basics.htm\#author 22. Serban M. Economic Discourse in Globalization. Ovidius University Annals. 2012. Vol. 12

23. The Analysis of Economics Discourse by Economists and Applied Linguists: A review. URL: http://www.isfla.org/Systemics/Print/ Theses/RoyceThesis/Chapter\%202\%20-\%20Review\%20of\%20Economics.pdf. No. 1. P. 666-670.

24. Widdowson H. G. Linguistics, 3d ed. Oxford : Oxford Univ. Press, 1997. 